ISSN electrónico: 2172-9077

DOI: https://doi.org/10.14201/fjc201919247249

\title{
HiSTORIAS DE LA CRISIS EN EL AUDIOVISUAL CONTEMPORÁNEO
}

\section{Stories of the Crisis in Contemporary Audiovisual Media}

\author{
Dra. Alba NAVARRO \\ Universidad de Málaga, España \\ E-mail: albanavarro@uma.es \\ (iD) http://orcid.org/0000-0002-3920-5471
}

Fecha de recepción de la reseña: 01/05/2019

Fecha de aceptación definitiva: 23/05/2019

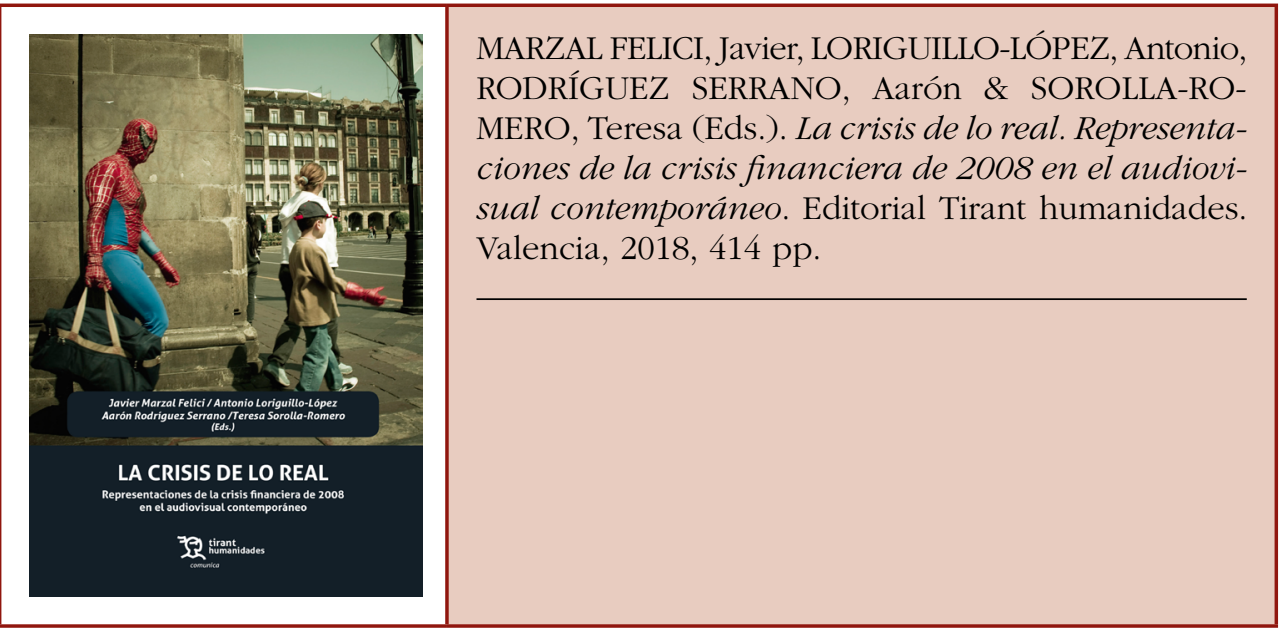

Los efectos de la crisis financiera iniciada en 2008 superan el plano meramente económico extendiéndose, inevitablemente, a otros niveles como el político, el social y el cultural. De igual modo, las reflexiones e interpretaciones surgidas a partir de sus causas y consecuencias han sido abordadas desde distintas disciplinas como el ensayo, la ficción literaria o la producción audiovisual. Son precisamente las representaciones proyectadas desde este último ámbito las que se constituyen como objeto de estudio en esta rigurosa publicación científica, compuesta por trece capítulos y coordinada por Javier Marzal Felici, Antonio Loriguillo-López, Aarón Rodríguez Serrano y Teresa Sorolla-Romero.

El libro comienza con un apartado elaborado por el propio Marzal Felici y María Soler Campillo, en el que son analizadas una serie de fotografías galardonadas en el 
World Press Photo y una muestra de cine documental y de ficción. En dichas obras audiovisuales -enmarcadas en la producción mainstream- predomina una concepción de la representación como espectáculo que deriva en una crítica superficial sobre el sistema económico, político, social y cultural. Tales cuestiones, podemos leer, se encuentran estrechamente ligadas a la legitimación del modelo económico neoliberal hegemónico.

En el siguiente capítulo, Marta Martín Núñez pone su atención en el trabajo de una nueva generación de fotógrafos españoles. Concretamente, se detiene en el estudio de cuatro proyectos que han sabido conectar con las realidades de la sociedad española en el contexto de la crisis económica. Las adversas consecuencias de este trance financiero, explica la autora, no solo han servido de impulso creativo para retratar la actualidad, sino que han puesto en entredicho el lenguaje hegemónico y las estructuras institucionales tradicionales de la fotografía en nuestro país.

A continuación, Shaila García Catalán nos habla de su interés por «leer aquellos gestos de la enunciación en nuestra cultura visual que revelan las tentativas de ocupar un Otro, que como lugar simbólico de la palabra, se ha esfumado». Así, entre otros aspectos, la investigadora nos advierte de cómo las ficciones audiovisuales anuncian, tratan y dan síntomas del modo en que nuestros líderes nos defraudan.

Aarón Rodríguez Serrano, por su parte, se decanta por un tema de gran singularidad. Nos referimos a la destrucción del estado de bienestar y su plasmación en el cine de terror contemporáneo. De manera específica, el teórico se refiere a las películas sobre casas encantadas, en las que ha podido observar un hecho novedoso que merece ser considerado: los personajes que son víctimas de las apariciones de los fantasmas no pueden cambiar de residencia a causa de la pobreza.

En otro orden de ideas, Teresa Sorolla-Romero reflexiona sobre las narrativas fracturadas postclásicas y el fenómeno de los mind-game films, centrando sus indagaciones en la película Abre los ojos (Alejandro Amenábar, 1997). Partiendo de este escenario, la autora se adentra en cuestiones tan complejas como la desconfianza hacia el progreso tecnológico, la obsesión por la conspiración ajena o la amnesia y la incertidumbre identitaria.

Del mismo modo, José Antonio Palao Errando se sumerge en el universo cinematográfico de la mano del POV Style y del filme Colossal (Nacho Vigalondo, 2016). Con ello, pretende poner en evidencia cómo la transparencia es el gran obstáculo para la producción de sentido. En relación con este argumento, el profesor afirma que «el cine se propone como interfaz del sentido frente a las demás pantallas, pero naufraga precisamente porque el mainstream le impide cuestionarse el propio horizonte hermenéutico".

Buceando en los usos visuales de la memoria y en las representaciones del pasado en el cine de lo real, encontramos a Roberto Arnau Roselló, quien sustenta su trabajo investigativo en tres momentos particulares de la historia del documento filmado. Las reflexiones de este autor nos llevan a transitar por el documental de propaganda en la II Guerra Mundial, el cine de lo real contemporáneo -de carácter ensayístico, autorreflexivo y subjetivo- y el documental interactivo o transmedia.

El séptimo arte ocupa también un lugar destacado en el apartado elaborado por Pablo Ferrando García y Francisco Javier Gómez Tarín, cuyas disertaciones tienen como punto de partida la representación de la realidad a través de la ficción y los mecanismos discursivos que la hacen posible. La propuesta de estos teóricos se 
desarrolla en torno a la cinta El hijo de Saúl (Saul fia, László Nemes, 2015), la cual «ha logrado conciliar perspectivas opuestas en la representación de lo irrepresentable».

En las líneas posteriores, las indagaciones de Nekane Parejo nos sitúan de lleno en el panorama audiovisual nórdico, en concreto, en la producción de la serie de trama policíaca Bron/Broen. Según la investigadora, más allá de la temática criminal, los capítulos plantean ciertas problemáticas que ponen de relieve las carencias y dilemas a los que se enfrenta el estado de bienestar, como la desigualdad económica, el papel desempeñado por los medios de comunicación o los movimientos migratorios. Todo ello, se suma a las complejas relaciones y conflictos familiares que presentan los personajes.

Seguidamente, Esteban Galán Cubillo lleva a cabo un estudio sobre la representación de la crisis en la ficción audiovisual española a través de las adaptaciones de dos relevantes novelas. Por una parte, señala el libro Crematorio (Rafael Chirbes, 2007), que ofrece un relato sobre la corrupción y las miserias ligadas al ladrillo. Este ha sido llevado a la pantalla en forma de serie por Sánchez Cabezudo. Por otra, nos habla de Tiempo de silencio (Martín Santos, 1962), obra ambientada en la España de posguerra que conoció su versión cinematográfica gracias a Vicente Aranda.

El periodo de crisis también ha dado lugar a la creación de movimientos organizados como el denominado \#Littlesecretfilm, surgido en el ámbito del cine español. De este asunto se encargan Agustín Rubio Alcover y Antonio Loriguillo-López, quienes realizan un recorrido desde sus orígenes hasta la actualidad, ofreciendo un exhaustivo análisis de sus intenciones, resultados y principales características.

Asimismo, Samuel Gil Soldevilla y Elvira Antón-Carrillo dedican el contenido de su capítulo al spot publicitario Despertar de Campofrío España. Los autores comentan que el anuncio puede catalogarse dentro de la tipología branding emocional, pues este tipo de publicidad trata de conectar de manera afectiva con la audiencia. A esto, añaden que la representación que hace de la crisis supone una legitimación de la ideología neoliberal presente en la sociedad. Por el contrario, existe un rechazo a cualquier intento de transformación del mundo a través de la política o la activación social.

En último lugar, citamos el trabajo desarrollado por Emilio Sáez Soro, quien parte de un escenario cultural en el que los videojuegos ocupan un espacio trascendental. Esta circunstancia ha contribuido a que sus mecánicas se trasladen a otras actividades no lúdicas. En este sentido, el teórico busca estudiar la coherencia y la utilidad del uso de la gamificación en ciertas áreas de interés.

La atenta lectura de estas páginas nos permite concluir que nos encontramos ante una obra poliédrica, respaldada por una extensa bibliografía y de gran valor científico. La crisis de lo real se erige, en definitiva, como una publicación de obligada consulta para aquellos que deseen comprender las formas, los significados y los sutiles matices que configuran las representaciones audiovisuales producidas con motivo de la crisis financiera iniciada en 2008. 